\title{
Is Trade Openness Good or Bad for Environment in Pakistan; an ARDL Bounds Testing Approach
}

\author{
Saima Ashraf AWAN $^{1, a}$, Muhammad Saeed MEO ${ }^{2, b}$, Amogh GHIMIRE ${ }^{1, c}$, \\ Ra-Yan WU ${ }^{1, \mathrm{~d}}$, Pei-Fen ZHUANG ${ }^{1, \mathrm{e}^{*}}$ \\ 1College of Economics, Fujian Agriculture and Forestry University, \\ Fuzhou-350002, China \\ 2Business Administration \& Management Sciences, \\ Superior University, Lahore-54000, Pakistan \\ asaimaok@hotmail.com, bsaeedk8khan@gmail.com, 'amoghimire@yahoo.com, \\ d2422876678@qq.com, epfzhuang@hotmail.com
}

Keywords: Trade openness, Environmental degradation, Foreign direct investment, ARDL approach.

\begin{abstract}
This study explored the relationship between trade openness, foreign direct investment, GDP, and environmental quality in Pakistan by using time series data for time period of 1971-2016.To examine long-run and short-run association among projected variables, we employed autoregressive distributed lag ARDL-bounds testing approach. The findings of the study confirmed a positive and significant long run association between trade openness, foreign direct investment, and environmental degradation in Pakistan. However, there is no relationship between GDP and environmental quality. Policymakers must consider environmental degradation due to trade openness and FDI; further environmental quality should not be ignored. The government must enforce environmental laws on local and international organizations.
\end{abstract}

\section{Introduction}

The worldwide environmental concerns due to adverse climate changes over planet earth have tended world economies towards the use of green energy along with considerable reduction in $\mathrm{CO}_{2}$ emission [1]. According to the recent studies, the large part of carbon emission is coming from the developing economies due to rapid economic growth. The globalization, where it benefits the developing economies to nurture their economies through reduced investment and trade barriers, opening of technology transfer, and mobilized capital and labor [2].

To investigate the real impact of trade on environment, various studies haveanalyzed the dynamic relationship between trade liberalization, energy usage and economic growth. Most of the researchers agreed at first that trade liberalization has improved allocation of domestic resources. Some studies found that liberalization of trade reduced pollution and decreased the use of energy efficiency. For example, the study by Sbia et al.[3] found that liberalization of trade enhanced the flows of new technology which substituted the old technology profoundly overwhelming the use of energy. Conversely, some studies found that liberalization of trade has deteriorated the environmental quality. The study by Lopez [4] shows that trade liberalization was tailed by an escalation in energy-based-events such as manufacturing and transportation that devour heavy energy and yield pollution.

The aim of this research is to investigate the economic impacts of the trade openness on the environmental quality in Pakistan. Specifically, the paper inspects whether openness of the trade has harmed the quality of the environment in Pakistan. For empirical results, we used ARDL approach for short run and long run.

The structure of the paper is as follows: Section 2 reviews the existing literature on the subject. Section 3 presents the model, methodology and data. Section 4 presents the empirical results and also discussion. The last section concludes the study. 


\section{Literature Review}

The correlation concerning trade liberalization, economic growth and the environmental quality has gained significant interest by scholars and policy makers during the last decade. Former studies classified this relationship in three categories. The first category is the scale effect in which trade openness is thought to fuel the domestic consumption and the level of production and hence speed up the economic activity. The second category is the technical effects which recommend that trade liberalization delivers the prospects of the transfer of advanced technology and reinforces the environmental regulation. The third category is the composition effect which acts when trade impacts on modeling the economic structure of the host country [5].

The impact of trade on the environmental quality has currently gained special consideration by scholars and policymakers. Essentially, the liberalization of the trade sector has directed to an extension of the international exchange events and the rush of FDI in manufacturing and energy-consuming sectors. As a result, the use of energy increased drastically, pollutant emissions surged and the environmental quality degenerated. All these factors have augmented the susceptibility of the ecosystem specifically in developing countries [6].

According to Aplay [7], the inconsistency of the consequence between the countries is based on many country-specific factors such as progress level of the countries, their comparative advantage, the resource intensity of the traded product, current level of environmental awareness, and the existence of environmental policies. Environmental economists including Grossman and Krueger [5], Bhagwati [8], Panayotou [9], Selden andSong [10], Grossman and Krueger [11], Ferrantino [12], Antweiler et al. [13], Ferrantino andLinkins [14], and Tsai [15] propose a positive relationship between free trade, economic growth and environmental policies. These authors discoursed that trade liberalization leads to a rise in welfare derived from a better allocation of domestic resources. In another opinion, ecological economists including Lopez [4], Cole et al. [16], Strutt and Anderson [17], disapproved the norms developed by environmental economists and recommend that trade liberalization will spawn negative environmental externalities especially when rich countries invest in dirty industries in host countries.

The studies which show trade openness influences negatively include; Suri and Chapman [18], Schmalensee et al [19]; Beghin et al [20]; Abler et al [21]; Lopez [22]; Cole et al [23] and Antweiler et al., [13]; Copeland and Taylor [24]; Chaudhuri and Pfaff, [25]; Ozturk and Acaravci [26] Nasir and Rehman [27], but it is also assumed that trade openness also helps to stand the negative effect in helping the economy pursued technology to achieve the efficiency, and after certain level of growth, the environmental degradation is also declined. Therefore, the mix results are found in literature regarding the impact of trade openness on fluctuating environmental quality.

\section{Methodology}

\section{The Data, Model and Methodology of the Study}

In this study, we used the following variables: trade openness (TOP), FDI, GDP and carbon dioxide $\left(\mathrm{CO}_{2}\right)$ emissions. $\mathrm{CO}_{2}$ emissions (measured in metric ton) are used as a proxy for environmental quality. Trade openness measures are used in this study such as trade volumes (import + export) as a share of GDP ratio. We also used the GDP and FDI inflow to $\mathrm{CO}_{2}$ as control variables. The yearly time series covers the period from 1971 to 2016. The main source of our data is provided by the World Bank [28]. All variables are transformed into log form. In this study, ARDL bound testing approach is applied to examine the effect of trade openness (TOP) on environmental quality.

\section{Econometric Mode}

$$
C O 2_{t}=\beta_{0}+\beta_{1}\left(T P_{t}\right)+\beta_{2}\left(F D I_{t}\right)+\beta_{3}\left(G D P_{t}\right)+u_{t}
$$

Where $\mathrm{CO}_{2}$, TP, FDI and GDP refers to $\mathrm{CO}_{2}$ emissions, trade openness, foreign direct investment and gross domestic product respectively. While, $\beta_{1}, \beta_{2}$, and $\beta_{3}$ are long run parameters. More importantly, traditional cointegration approaches by Engle and Granger [29], Johansen [30, 31], and 
Johansen-Juselius [32] have a precondition that all the variables must be stationary at I(1) and one limitation of the mentioned approaches was that these cointegration tests perform poor in small sample size, therefore, to overcome said limitation, we employed ARDL approach advanced by Pesaran, Shin and Smith [33], Pesaran and Shin [34], and Pesaran et al. [35]. For the ARDL model, stationary checking is not required, but ARDL approach can be applied in the presence of I(2) variable, because in the presence of I(2) or above, variables computed f-statistics are not valid [36].

Taking into account of benefits of ARDL model, we specified following ARDL long run equation, however, in Equation 1 we can only find long run coefficients while for long run and short run coefficient, we formulated following ARDL equation.

$$
\begin{gathered}
\Delta C O 2_{t}=\theta+\sum_{k=1}^{P 1} \theta_{k} \Delta C O 2_{t-k}+\sum_{k=1}^{P 2} \theta_{k} \Delta T P_{t-k}+\sum_{k=1}^{P 3} \theta_{k} \Delta F D I_{t-k}+\sum_{k=1}^{P 4} \theta_{k} \Delta G D P_{t-k}+ \\
\lambda_{1} C O 2_{t-1}+\lambda_{2} T P_{t-1}+\lambda_{2} F D I_{t-1}+\lambda_{3} G D P_{t-1}+\mu_{t}
\end{gathered}
$$

\section{Empirical Findings}

Before testing long run association among projected variables, we checked unit root of the series and it is confirmed that there was no variables stationary at $\mathrm{I}(2)$. Therefore, we could test either long run exists or not between $\mathrm{CO}_{2}$, TOP, FD and GDP, Table 1 includes unit root results. Furthermore, bounds test results showed that cointegration exists in purposed variables. F-statistic value was 6.6088 that was higher than upper bound value which was 5.0700.

Table 1. Unit Root Test (ADF) Results

\begin{tabular}{|c|c|c|}
\hline Variable s & Unit root at level I(0) & Unit root at first difference I(1) \\
\hline LnCO $_{2}$ & 1.1995 & -1.958 \\
& $(0.9392)$ & $(0.0488)$ \\
\hline LnTOP & -3.2124 & -9.0357 \\
& $(0.0253)$ & $(0.0000)$ \\
\hline LnFDI & -1.7858 & -4.4760 \\
& $(0.0706)$ & $(0.0000)$ \\
\hline LnGDP & .1746 & -4.7425 \\
& $(.9000)$ & $(0.0003)$ \\
\hline
\end{tabular}

Table 2. ARDL Model Long -run Results

\begin{tabular}{|c|c|c|}
\hline \multirow{2}{*}{ Variables } & Long run parameters & Short run parameters \\
\cline { 2 - 3 } LnTOP & Coefficients (prob) & Coefficients (prob) \\
& 1.0833 & 0.2205 \\
& $(0.0609)^{* * *}$ & $(0.0026)^{*}$ \\
\hline \multirow{2}{*}{ LnFDI } & 0.1752 & 0.0130 \\
& $(0.0105)^{* *}$ & $(0.2193)$ \\
\hline \multirow{2}{*}{ LnGDP } & -0.3050 & -0.0621 \\
& $(0.2488)$ & $(0.3105)$ \\
\hline \multirow{2}{*}{ C } & 10.1398 & ------------ \\
\hline \multirow{2}{*}{ @TREND } & $(0.1018)$ & 0.0094 \\
& 0.0462 & $(0.1352)$ \\
\hline
\end{tabular}

Note: Error correction term is $-0.204^{*}$, Jarque- Bera $0.121^{* *}$, Breusch-Godfrey Serial Correlation LM Test $0.441^{* *}$, and Heteroscedasticity $0.312^{* *}$

$*, * *, \&^{* * *}$ refer to significance at $1 \%, 5 \%$ and $10 \%$ respectively

Table 2 showed the results of long run and short run parameters. The findings of the study showed that there is a positive and significant association between trade openness, FDIand environmental degradation. It impliedthat in a long run, due to increase in trade openness and FDI, there wassurge in 
environmental degradation/damage. While GDP showedno significant link with environmental degradation in long run as well as in short-run. The findings of the study werealigned with Grossman and Krueger [11], and Hakimi and Hamdi [6]. Furthermore, the error correction term wastelling 20\% speed of adjustment in each year. While, we also employed different diagnostics test such as normality test, serial correlation test and Heteroscedasticity test, and it wasfound that the model surpassed all the major issues so we couldrely on the ARDL calculated results. Finally, we also tested parameters stability with the help of CUSUM and CUSUMsq tests as showed in Figure 1. Moreover, both testsconfirmed that parameters werestable, and there wasno problem of possible structural breaks.

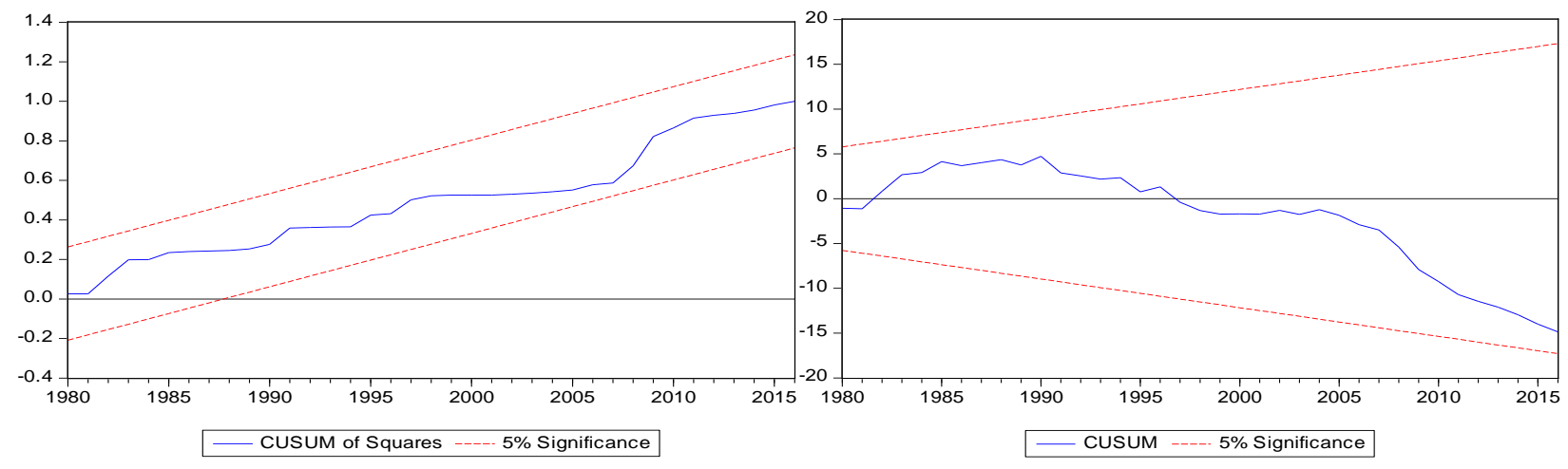

Figure 1: CUSUM and CUSUMsq Tests Showing Parameters Stability

\section{Conclusions}

This study explored the relationship between trade openness, FDI, GDP and environmental quality in Pakistan by using time series data for the time period of 1971-2016. To examine the long-run and short-run association among projected variables, we employed autoregressive distributed lag ARDL-bounds testing approach. The findings of the study confirmed a positive and significant long run association between trade openness, FDI, and environmental degradation in Pakistan. The policy makers must consider environmental issues into account for the betterment of human lives. The government must enforce environmental laws on local and international organizations.

Conflict of interest: The authors declare that there is no conflict of interest.

\section{References}

[1] Ahmed, K. and W. Long, Environmental Kuznets curve and Pakistan: an empirical analysis. Procedia Economics and Finance, 2012. 1: p. 4-13.

[2] Costanza, R., et al., An introduction to ecological economics. 2014: CRC Press.

[3] Sbia, R., M. Shahbaz, and H. Hamdi, A contribution of foreign direct investment, clean energy, trade openness, carbon emissions and economic growth to energy demand in UAE. Economic Modelling, 2014. 36: p. 191-197.

[4] Lopez, R., Environmental externalities in traditional agriculture and the impact of trade liberalization: the case of Ghana. Journal of Development Economics, 1997. 53(1): p. 17-39.

[5] Grossman, G.M. and A.B. Krueger, Environmental impacts of a North American free trade agreement. 1991, National Bureau of Economic Research.

[6] Hakimi, A. and H. Hamdi, Trade liberalization, FDI inflows, environmental quality and economic growth: a comparative analysis between Tunisia and Morocco. Renewable and Sustainable Energy Reviews, 2016. 58: p. 1445-1456.

[7] Alpay, S., What Do We Know about the Interactions Between Trade and the Environment?: A 
Survey of the Literature. 1999: Bilkent University.

[8] Bhagwati, J.N. and T. Srinivasan, Trade and the environment: Does environmental diversity detract from the case for free trade? 1995: Columbia University, Department of Economics.

[9] Panayotou, T., Empirical tests and policy analysis of environmental degradation at different stages of economic development. 1993.

[10]Selden, T.M. and D. Song, Environmental quality and development: is there a Kuznets curve for air pollution emissions? Journal of Environmental Economics and management, 1994. 27(2): p. 147-162.

[11]Grossman, G.M. and A.B. Krueger, Economic growth and the environment. The quarterly journal of economics, 1995. 110(2): p. 353-377.

[12]Ferrantino, M.J., International trade, environmental quality and public policy. The World Economy, 1997. 20(1): p. 43-72.

[13] Antweiler, W., B.R. Copeland, and M.S. Taylor, Is free trade good for the environment? American Economic Review, 2001. 91(4): p. 877-908.

[14]Ferrantino, M.J. and L.A. Linkins, The effect of global trade liberalization on toxic emissions in industry. Weltwirtschaftliches Archiv, 1999. 135(1): p. 128-155.

[15]Tsai, P.-L., Is trade liberalization harmful to the environment? An alternative view. Journal of Economic Studies, 1999. 26(3): p. 201-209.

[16]Cole, M.A., A.J. Rayner, and J.M. Bates, The environmental Kuznets curve: an empirical analysis. Environment and development economics, 1997. 2(4): p. 401-416.

[17] Strutt, A. and K. Anderson, Will trade liberalization harm the environment? The case of Indonesia to 2020. Environmental and Resource Economics, 2000. 17(3): p. 203-232.

[18]Suri, V. and D. Chapman, Economic growth, trade and energy: implications for the environmental Kuznets curve. Ecological economics, 1998. 25(2): p. 195-208.

[19]Schmalensee, R., T.M. Stoker, and R.A. Judson, World carbon dioxide emissions: 1950-2050. Review of Economics and Statistics, 1998. 80(1): p. 15-27.

[20]Beghin, J.C., et al., Trade integration, environmental degradation, and public health in Chile: assessing the linkages. Environment and Development Economics, 2002. 7(2): p. 241-267.

[21]Abler, D.G., A.G. Rodriguez, and J.S. Shortle, Trade liberalization and the environment in Costa Rica. Environment and Development Economics, 1999. 4(3): p. 357-373.

[22]Lopez, R., The environment as a factor of production: the effects of economic growth and trade liberalization. Journal of Environmental Economics and management, 1994. 27(2): p. 163-184.

[23]Cole, M.A., R.J. Elliot, and A.K. Azhar, The determinants of trade in pollution intensive industries: North-South evidence. 2001: University of Birmingham.

[24]Copeland, B.R. and M.S. Taylor, International trade and the environment: a framework for analysis. 2001, National bureau of economic research.

[25]Chaudhuri, S. and A. Pfaff, Economic growth and the environment: what can we learn from household data. Columbia University, February, 2002.

[26] Ozturk, I. and A. Acaravci, CO2 emissions, energy consumption and economic growth in Turkey. Renewable and Sustainable Energy Reviews, 2010. 14(9): p. 3220-3225.

[27]Nasir, M. and F.U. Rehman, Environmental Kuznets curve for carbon emissions in Pakistan: an empirical investigation. Energy Policy, 2011. 39(3): p. 1857-1864. 
[28]World Bank. World Development indicators. Washington DC. 2016.

[29]Engle, R.F. and C.W. Granger, Co-integration and error correction: representation, estimation, and testing. Econometrica: journal of the Econometric Society, 1987: p. 251-276.

[30]Johansen, S., Statistical analysis of cointegration vectors. Journal of economic dynamics and control, 1988. 12(2-3): p. 231-254.

[31]Johansen, S., Estimation and hypothesis testing of cointegration vectors in Gaussian vector autoregressive models. Econometrica: Journal of the Econometric Society, 1991: p. 1551-1580.

[32]Johansen, S. and K. Juselius, Maximum likelihood estimation and inference on cointegration -with applications to the demand for money. Oxford Bulletin of Economics and statistics, 1990. 52(2): p. 169-210.

[33]Pesaran, M.H. and Y. Shin, An autoregressive distributed-lag modelling approach to cointegration analysis. Econometric Society Monographs, 1998. 31: p. 371-413.

[34]Pesaran, M.H., Y. Shin, and R.P. Smith, Pooled mean group estimation of dynamic heterogeneous panels. Journal of the American Statistical Association, 1999. 94(446): p. 621-634.

[35]Pesaran, M.H., Y. Shin, and R.J. Smith, Bounds testing approaches to the analysis of level relationships. Journal of applied econometrics, 2001. 16(3): p. 289-326.

[36]Ouattara, Modelling the Long Run Determinants of Private Investment in Senegal. Centre for Research in Economic Development and International Trade, University of Nottingham, 2004. 